\title{
EGG PRODUCTION PERFORMANCE, BLOOD BIOCHEMICAL AND IMMUNOLOGICAL RESPONSE OF LAYING JAPANESE QUAIL FED DIET SUPPLEMENTED WITH PROPOLIS AND BEE POLLEN
}

\author{
A.A. Desoky ${ }^{1}$ and Nancy N. Kamel ${ }^{2}$ \\ ${ }^{1}$ Department of Animal Production, Faculty of Agriculture, Cairo University, Egypt. \\ ${ }^{2}$ Department of Animal Production, National Research Center, Dokki, Giza, Egypt.
}

(Received 3/5/2018, accepted 19/6/2018)

\section{SUMMARY}

$\mathrm{I}$

Increasing productivity, improving product quality and insuring animal welfare are general demands to animal breeders. The aim of this study was to evaluate the effect of supplementing the diet with propolis and/or bee pollen on egg productivity and immunological responses of laying Japanese quail. A total of 200 female quail, 35 days old, were randomly allocated to four equal groups. The first group served as a control group and was fed a basal diet (C). The second group was fed the basal diet supplemented with propolis at $1 \mathrm{~g} / \mathrm{kg}$ diet (Pro). The third group was fed the basal diet supplemented with bee pollen at $2 \mathrm{~g} / \mathrm{kg}$ diet $(\mathrm{Bp})$. The fourth group was fed the basal diet supplemented with both propolis $(1 \mathrm{~g} / \mathrm{kg}$ diet) and bee pollen $(2 \mathrm{~g} / \mathrm{kg}$ diet $)($ Pro $+\mathrm{Bp})$. Feed intake, feed conversion, egg mass, shell thickness and yolk index were significantly improved due to different dietary supplementation. Blood total protein and albumin increased, whereas cholesterol and $\mathrm{H} / \mathrm{L}$ ratio significantly decreased due to diet supplementation. A synergistic effect of Pro+Bp was noticed in blood albumin, calcium and $\mathrm{H} / \mathrm{L}$ ratio. In conclusion propolis and bee pollen can be supplemented to the diet of laying quail to increase egg production, improve egg quality and enhance blood protein, lipid and immunological responses.

Keywords: propolis, bee pollen, quail, production performance, egg quality, blood parameters.

\section{INTRODUCTION}

The Japanese quail (Coturnix coturnix japonica) has relative advantages compared to other poultry species. These advantages have been summarized as: 1) Dual purpose poultry species producing eggs and meat, 2) Low maintenance cost with short generation interval, high egg production and diseases resistance, 3) Japanese quail is the smallest avian species farmed for meat and egg (Vali, 2008 and Mohammed and Ejiofor, 2015). Quail egg yolk has the highest monounsaturated fatty acid (MUSFA) reaching 51.6\% and $12 \%$ polyunsaturated fatty acid (PUFA) compared to other wild birds maintained in captivity (Choi et al., 2001). Al-Obaidi and Al-Shadeedi (2017) found no significant differences between chicken and quail egg in albumin content (11.76 vs. $11.80 \%)$ and egg yolk content (17.59 vs. $15.58 \%)$, respectively. They also found that quail egg cholesterol and LDL (mg/g) levels were significantly lower than in the chicken egg. These findings imply that the quail egg is relatively healthier than the chicken egg especially for people suffering from cardiac problems. Loetscher et al. (2014) reported a significant transfer of antioxidants from the diet supplemented with antioxidants to the hen egg, and they claimed that using natural plant-origin additives with antioxidant properties is suggested to support eggs with relatively high antioxidant properties. Therefore, the high concentrations of MUFA and PUFA in quail egg require powerful antioxidant supplementation to protect these fatty acids from oxidation. Poultry feed must be formulated to provide all the nutrients necessary for growth and health. The naturally available growth factors, probiotics and antimicrobial peptides, ought to be used due to their lower side effects on bird wellbeing and the health status of the consumers (Keerthana and Renuka, 2017). Propolis and bee pollen were suggested as natural growth- 


\section{Desoky and Kamel}

promoter substitutions of antibiotics in poultry diets (Kročko et al., 2012; Babaei et al., 2016; Haščík et al., 2017; Khan, 2017). Propolis is a resin substance collected from plant by honeybees (Apis mellifera) and is used in disease resistance inside bee hives (Simone-Finstrom and Spivak, 2010). It has a wide range of biological effects such as immunomodulatory, anti-microbial, anti-viral, anti-fungal, anti-inflammatory and anti-tumor activities (Lotfy, 2006; Viuda-Martos et al., 2008). Bee pollen is another product of honeybees that is collected for the purpose of feeding their larvae in the early stages of development and is considered the main source of proteins, minerals and fats (Campos et al., 2008). On the other hand, bee pollen is composed of different bioactive substances such as essential amino acids, lipids, glucosinolates, phenolic compounds, vitamins and minerals that make it an attractive natural healthy food (Roulston and Cane, 2000; Ares et al., 2018). The antimicrobial, antimutagenic, antioxidant and anti-inflammatory activities of bee pollen are well documented (Pascoal et al., 2014). Broad scopes of positive immunological, histological and productive effects were observed when propolis and/or bee pollen were supplemented to poultry diet. Increasing feed intake, body weight gain and improving feed conversion ratio were common effects of the use of propolis and/or bee pollen supplementation in broiler, quail and rabbit diets (Attia et al., 2011ab; Hosseini et al., 2016; Mehaisen et al., 2017). The immunological status of broiler chicken was enhanced with bee pollen supplementation (Oliveira et al., 2013). Research investigations studied the effects of propolis and bee pollen supplementation on alleviation the negative effect of heat stress oxidative damage in growing and laying quail. Significant effects of propolis and bee pollen supplementation to quail diet on the productive performance, immunological response and blood lipid profile were reported (Zeweil et al., 2016; Mehaisen et al., 2017). The present study aimed to investigate the effects of propolis and bee pollen supplementation to the diet on productive performance, egg quality, blood constituents and immunity parameters of laying

Japanese quail reared under thermo-neutral environment and to find out if there is a synergistic effect between the two supplementations on quail productive performance.

\section{MATERIALS AND METHODS}

\section{Birds management:}

A total of 200 female Japanese quail, 35 days old, were allocated randomly to four equal groups. Birds were distributed into 20 wired-cages [10 birds per cage, measured $60 \times 50 \times 50 \mathrm{~cm}$ for length, width and height, respectively] in an environmentally-controlled room. The brooding temperature was daily recorded three times at 8 a.m. 3 p.m. and 8 p.m. using digital thermometer and was found to be ranged from $25.4 \pm 0.5$ to $27.3 \pm 0.4^{\circ} \mathrm{C}$. The relative humidity was 50 to $60 \%$. Lighting was set to provide birds with $16 \mathrm{~h}$ light and $8 \mathrm{~h}$ dark daily throughout the experiment.

\section{Experimental design:}

The birds were randomly divided into four groups. The first group was fed the basal diet without any supplementation and served as the control (C). The second group was fed the basal diet supplemented with propolis at $1 \mathrm{~g} / \mathrm{kg}$ diet (Pro). The third group was fed the basal diet supplemented with bee pollen at $2 \mathrm{~g} / \mathrm{kg}$ diet (Bp). The fourth group was fed propolis $(1 \mathrm{~g} / \mathrm{kg})$ and bee pollen $(2 \mathrm{~g} / \mathrm{kg}),($ Pro $+\mathrm{Bp})$. Feeding regime was started at 35 days of age and ended at 84 days of age. The first seven days were set as adaptation period and the parameters were taken starting from 42 to 84 days of age

\section{Egg production and egg quality:}

The initial and final body weights ( $\mathrm{g}$ ) were individually recorded at the beginning and at the end of the experiment (42 and $84 \mathrm{~d}$ of age). Egg number and egg weight were recorded daily, and egg mass was calculated for each group. The feed intake (g/bird/d) was measured for each treatment group. The feed conversion ratio was calculated for each treatment.

At the end of the experiment, 15 eggs were chosen randomly from each group. Egg weight was measured to the nearest $0.1 \mathrm{~g}$. Egg width and egg length $(\mathrm{cm})$ were calibrated using an electronic digital device. Egg shape index was calculated according to Das et al. (2010) as: (egg width/egg length) $\times 100$. 
Eggshell thickness $(\mathrm{mm})$ was measured once the egg shell was dried at room temperature, recorded as the average of estimates from both ends and the equator of the examined eggs (Das et al., 2010). Eggshell weight (g) was determined after the shell had been dried at room temperature. Egg shell ratio was calculated as: (shell weight/egg weight) $\times 100$.

Internal egg quality parameters were also measured. The yolk was gently separated from the albumin and weighed. The albumen mass was calculated by subtracting the shell and yolk weights from the total egg weight. The yolk and albumen dimensions $(\mathrm{mm})$ were estimated according to Reddy et al. (1979). Yolk index was calculated as: [yolk height $(\mathrm{cm}) /$ yolk diameter $(\mathrm{cm})] \times 100$. Yolk ratio was calculated as: (yolk weight $(\mathrm{g}) /$ egg weight $(\mathrm{g}) \times 100)$. Albumen ratio was computed as: [albumen weight $(\mathrm{g}) /$ egg weight $(\mathrm{g})] \times 100$ (Romanoff and Romanoff, 1949). The Haugh units were determined using the following formula: $\log$ [albumen height $\left.(\mathrm{mm})+7.57-1.7 \times(\text { egg weight }(\mathrm{g}))^{0.37}\right] \times 100$, (Haugh, 1937).

The birds were fed a basal diet (Table 1) according to NRC (1994) guideline. The diet and fresh water were provided ad libitum.

Table (1): Basal diet composition and calculated analysis.

\begin{tabular}{lc}
\hline Ingredient & $\%$ \\
\hline Yellow corn & 64.50 \\
Soybean meal, 44\% & 20.50 \\
Protein concentrate, 52\% & 10.00 \\
Di-calcium phosphate & 2.31 \\
Limestone & 0.96 \\
Lysine & 0.08 \\
DL-methionine & 0.09 \\
Premix & 1.06 \\
Vitamin and trace mineral & 0.40 \\
Coccidostate & 0.10 \\
Calculated analysis & \\
ME (kcal/kg) & 2853 \\
Crude protein, $\%$ & 20.00 \\
Calcium, \% & 2.33 \\
Available phosphorus, $\%$ & 0.66 \\
Lysine, $\%$ & 1.04 \\
Methionine, $\%$ & 0.52 \\
\hline
\end{tabular}

\section{Blood sampling and analysis:}

Twelve blood samples from each experimental group were collected biweekly in two heparinized tubes. One tube was centrifuged at $2000 \times \mathrm{g}$ for $10 \mathrm{~min}$ at $4{ }^{\circ} \mathrm{C}$, and plasma was separated and stored at $-20^{\circ} \mathrm{C}$ until further analysis. The plasma total protein, albumin, cholesterol, triglycerides, calcium, phosphorus, AST and ALT were measured in plasma using kits (Salucea, Haansberg, Netherlands).

The other heparinized tube was assigned to measure the total white blood cells (TWBCs) and the heterophil/lymphocyte $(\mathrm{H} / \mathrm{L})$ ratio. The TWBCs were manually determined by mixing $490 \mu \mathrm{l}$ of brilliant cresyl blue dye with $10 \mu \mathrm{l}$ of the whole blood sample, and then the total leukocytes were counted under a microscope at a magnification of 200x using a hemocytometer slide (Gehad et al., 2008). The H/L ratio was determined using Hema-3 stain (cat\# 22-122911, Fisher scientific, USA), according to Zhang et al., (2009). 


\section{Desoky and Kamel}

\section{Statistical analysis:}

Statistical analysis was performed using the general linear model (GLM) procedure of SAS (2006) considering the treatment effect. Differences among means were obtained using Duncan's new multiple range test at $\mathrm{P}<0.05$ (Duncan, 1955).

\section{RESULTS AND DISCUSSION}

\section{Production performance:}

The production performance parameters are presented in Table (2). The mean initial and final body weight were $252 \pm 1$ and $342 \pm 1 \mathrm{~g}$, respectively, and the differences between experimental groups were insignificant. Feed intake was significantly increased $(\mathrm{P}<0.0001)$ in all the supplemented groups by about $11 \%$ compared to the control group. Feed conversion was improved by about $13 \%$ when diet was supplemented with Pro, Bp or both Pro+Bp. These results can be explained by the reported effects of propolis and bee pollen on increasing the crypts depth in quail ileum (Mehaisen et al., 2017) and in broiler jejunum (Hosseini et al., 2016). Moreover, Wang et al. (2007) reported that when bee pollen was supplemented to the diet of broiler chickens, a trophic effect was shown by increasing thickness and length of the small intestine villi. These findings have a direct effect of propolis and bee pollen on increasing nutrients absorption and consequently improving feed conversion ratio. Another explanation was suggested by Kročko et al. (2012) that propolis and bee pollen supplementations modulated the bacterial colonization pattern in favor to beneficial microorganisms in broiler chickens.

Table (2): Performance and egg production parameters of Japanese quail supplemented with propolis (Pro), bee pollen (Bp) or both (Pro+Bp).

\begin{tabular}{lccccc}
\hline Item & C & Pro & Bp & Pro+Bp & $P$-value \\
\hline Initial body weight, g & $249 \pm 2$ & $252 \pm 3$ & $251 \pm 2$ & $255 \pm 2$ & 0.354 \\
Final body weight, g & $340 \pm 2$ & $343 \pm 2$ & $340 \pm 2$ & $345 \pm 2$ & 0.277 \\
Feed intake, g/bird/d & $21.27 \pm 0.12^{\mathrm{b}}$ & $23.68 \pm 0.02^{\mathrm{a}}$ & $23.73 \pm 0.09^{\mathrm{a}}$ & $23.48 \pm 0.11^{\mathrm{a}}$ & 0.0001 \\
Feed conversion & $3.45 \pm 0.41^{\mathrm{a}}$ & $2.97 \pm 0.28^{\mathrm{b}}$ & $3.06 \pm 0.28^{\mathrm{b}}$ & $2.94 \pm 0.28^{\mathrm{b}}$ & 0.006 \\
Egg number, bird/d & $0.52 \pm 0.06^{\mathrm{b}}$ & $0.64 \pm 0.06^{\mathrm{a}}$ & $0.63 \pm 0.05^{\mathrm{ab}}$ & $0.64 \pm 0.06^{\mathrm{a}}$ & 0.0001 \\
Egg weight, g & $12.16 \pm 0.25^{\mathrm{b}}$ & $12.59 \pm 0.12^{\mathrm{a}}$ & $12.44 \pm 0.20^{\mathrm{ab}}$ & $12.59 \pm 0.12^{\mathrm{a}}$ & 0.027 \\
Egg mass, d & $6.36 \pm 0.80^{\mathrm{c}}$ & $8.13 \pm 0.79^{\mathrm{a}}$ & $7.89 \pm 0.70^{\mathrm{b}}$ & $8.16 \pm 0.81^{\mathrm{a}}$ & 0.0001 \\
\hline
\end{tabular}

Means within the same row with different superscripts differ significantly $(P \triangleleft 0.05)$.

On the other hand, egg production (number of eggs per day) was significantly increased with propolis supplementation, with or without bee pollen, compared to the control group. Also, egg weight showed a significant increase in the Pro and Pro+Bp groups and a tendency of increasing egg weight in the Bp group. These results are closely related to the high feed intake and improved feed conversion that were observed in each of the supplemented groups.

\section{Egg quality}

The internal and external egg quality parameters are presented in Table (3). The supplementation of diet with Pro, Bp and Pro+Bp resulted in significant increases in shell thickness and yolk index compared to the control. The significant increases in shell weight and shell percentage were prominent in the Pro and Pro+Bp groups. The egg quality parameters are all in agreement with the result of El-Tarabany (2016) in Japanese quail. It can be implied that the observed differences in yolk parameter due to treatment can be partially attributed to the increasing level of sexual hormones, estrogen and progesterone as reported by Attia et al. 
(2011a) in rabbits fed bee pollen in diet. Estrogen increases the production of yolk precursors in the liver and results in changes in the calcium bone mobilization facilitating eggshell production.

Table (3): Egg quality parameters of Japanese quail supplemented with propolis (Pro), bee pollen (Bp) or both (Pro+Bp).

\begin{tabular}{lccccc}
\hline Egg Quality Parameters & C & Pro & Bp & Pro+Bp & $P$-value \\
\hline Egg weight, g & $12.87 \pm 0.22$ & $13.27 \pm 0.37$ & $13.00 \pm 0.34$ & $13.27 \pm 0.23$ & 0.714 \\
Shape index \% & $78.99 \pm 0.87$ & $79.62 \pm 1.17$ & $79.44 \pm 0.63$ & $79.80 \pm 0.80$ & 0.928 \\
Shell weight, g & $1.07 \pm 0.02^{\mathrm{b}}$ & $1.18 \pm 0.03^{\mathrm{a}}$ & $1.13 \pm 0.04^{\mathrm{ab}}$ & $1.19 \pm 0.02^{\mathrm{a}}$ & 0.007 \\
Shell \% & $8.04 \pm 0.19^{\mathrm{b}}$ & $8.97 \pm 0.29^{\mathrm{a}}$ & $8.83 \pm 0.40^{\mathrm{ab}}$ & $8.99 \pm 0.23^{\mathrm{a}}$ & 0.043 \\
Shell thickness, mm & $0.27 \pm 0.004^{\mathrm{b}}$ & $0.29 \pm 0.004^{\mathrm{a}}$ & $0.30 \pm 0.005^{\mathrm{a}}$ & $0.30 \pm 0.004^{\mathrm{a}}$ & 0.0001 \\
Yolk weight, g & $4.46 \pm 0.16$ & $4.67 \pm 0.16$ & $4.55 \pm 0.14$ & $4.67 \pm 0.13$ & 0.720 \\
Yolk \% & $34.65 \pm 1.03$ & $35.44 \pm 1.37$ & $35.30 \pm 1.31$ & $35.29 \pm 1.03$ & 0.967 \\
Yolk index, \% & $38.83 \pm 0.10^{\mathrm{b}}$ & $42.27 \pm 1.07^{\mathrm{a}}$ & $41.95 \pm 0.70^{\mathrm{a}}$ & $42.29 \pm 0.51^{\mathrm{a}}$ & 0.013 \\
Albumen weight & $7.35 \pm 0.18$ & $7.42 \pm 0.38$ & $7.31 \pm 0.36$ & $7.41 \pm 0.23$ & 0.992 \\
Albumen, \% & $57.04 \pm 0.10$ & $55.61 \pm 1.46$ & $55.86 \pm 1.51$ & $55.73 \pm 1.15$ & 0.855 \\
Haugh Unit & $85.57 \pm 0.95$ & $86.28 \pm 0.66$ & $85.35 \pm 1.39$ & $86.44 \pm 0.77$ & 0.829 \\
\hline
\end{tabular}

Means within the same row with different superscripts differ significantly $(P \varangle 0.05)$.

\section{Blood biochemistry and immune parameters}

Plasma biochemical and immunological parameters of mature female quail supplemented with Pro and/or Bp are presented in Table (4). Dietary supplementation significantly increased plasma total protein, albumin and globulin level $(\mathrm{P}<0.05)$. A synergistic effect was noticed in plasma albumin level when comparing Pro+Bp group with the other supplemented and non-supplemented control groups.

Plasma calcium was increased in the Pro+Bp group compared to the control group $(\mathrm{P}<0.05)$. The tendency of increasing plasma calcium level in the Pro and Bp groups and the significant increase of plasma calcium in Pro+Bp group may indicate the improvement of calcium metabolism due to the Pro and Bp supplementations, and in turn, significant high shell weight, thickness and percentage were observed (Table 3). The mineral elements of bee pollen showed a predominance of $\mathrm{K}, \mathrm{P}, \mathrm{Ca}$, and $\mathrm{Mg}$ (Bonvehí and Jordà, 1997). Significant reduction in AST activity was observed in supplemented groups compared to the control group indicating positive effect on liver function and activity.

Table (4): Plasma biochemistry and immunological parameters of Japanese quail supplemented with propolis (Pro), bee pollen (Bp) or both (Pro+Bp).

\begin{tabular}{lccccc}
\hline Blood parameter & Control & Pro & Bp & Pro+Bp & $P$-value \\
\hline Total protein, g/dl & $4.37 \pm 0.30^{\mathrm{b}}$ & $5.87 \pm 0.16^{\mathrm{a}}$ & $5.80 \pm 0.26^{\mathrm{a}}$ & $6.12 \pm 0.16^{\mathrm{a}}$ & 0.0001 \\
Albumin g/dl & $2.22 \pm 0.10^{\mathrm{c}}$ & $2.78 \pm 0.10^{\mathrm{b}}$ & $2.64 \pm 0.15^{\mathrm{b}}$ & $3.12 \pm 0.09^{\mathrm{a}}$ & 0.0001 \\
Globulin, g/dl & $2.15 \pm 0.30^{\mathrm{b}}$ & $3.08 \pm 0.16^{\mathrm{a}}$ & $3.16 \pm 0.34^{\mathrm{a}}$ & $3.00 \pm 0.20^{\mathrm{a}}$ & 0.030 \\
Calcium, mg/dl & $8.75 \pm 0.41^{\mathrm{b}}$ & $10.11 \pm 0.54^{\mathrm{b}}$ & $9.97 \pm 0.50^{\mathrm{ab}}$ & $10.57 \pm 0.61^{\mathrm{a}}$ & 0.0475 \\
Phosphorus, mg/dl & $6.41 \pm 0.27$ & $6.77 \pm 0.36$ & $6.60 \pm 0.28$ & $6.84 \pm 0.28$ & 0.746 \\
AST, U/l & $24.17 \pm 1.95^{\mathrm{a}}$ & $17.94 \pm 2.10^{\mathrm{b}}$ & $17.24 \pm 1.62^{\mathrm{b}}$ & $16.32 \pm 1.84^{\mathrm{b}}$ & 0.050 \\
ALT, U/l & $12.14 \pm 1.08$ & $12.02 \pm 1.30$ & $12.17 \pm 1.19$ & $11.99 \pm 1.01$ & 0.999 \\
Cholesterol, mg/dl & $202 \pm 8.56^{\mathrm{a}}$ & $170 \pm 5.91^{\mathrm{b}}$ & $170 \pm 4.37^{\mathrm{b}}$ & $160 \pm 6.01^{\mathrm{b}}$ & 0.0002 \\
Triglycerides, mg/dl & $218 \pm 8.91^{\mathrm{a}}$ & $186 \pm 10.30^{\mathrm{b}}$ & $192 \pm 9.01^{\mathrm{ab}}$ & $183 \pm 10.87^{\mathrm{b}}$ & 0.045 \\
TWBCs, $\times 10^{3} / \mathrm{mm}^{3}$ & $109 \pm 5.49$ & $113 \pm 4.77$ & $107 \pm 4.60$ & $114 \pm 6.51$ & 0.798 \\
H/L ratio & $0.46 \pm 0.01^{\mathrm{a}}$ & $0.32 \pm 0.01^{\mathrm{bc}}$ & $0.34 \pm 0.02^{\mathrm{b}}$ & $0.30 \pm 0.01^{\mathrm{c}}$ & 0.0001 \\
\hline
\end{tabular}

Means within the same row with different superscripts differ significantly $(P<0.05)$.

*: globulin was calculated by subtracting plasma albumin from total protein. 


\section{Desoky and Kamel}

Cholesterol level was significantly decreased due to Pro and Bp supplementation. The combination of Pro and Bp supplementation tended to show a further reduction in cholesterol level compared to each supplementation alone (160 vs. $170 \mathrm{mg} / \mathrm{dl}$, respectively). Triglycerides levels were also significantly decreased in the Pro and Pro+Bp groups. Similar significant reduction in serum cholesterol and triglycerides in broiler chickens fed propolis and/or bee pollen continuously or intermittently were obtained by Attia et al. (2014). Also, propolis supplementation to broiler chickens reduced cholesterol and triglycerides when fed at $0.8 \mathrm{~g} / \mathrm{kg}$ diet (Zafarnejad et al., 2017). The reduction in serum cholesterol and triglycerides were also reported by Farag and El-Rayes (2016) in broilers chicks fed bee pollen, demonstrating negatively related dose depended pattern. Therefore, the significance of reduction in triglycerides in Bp group can be attributed to the dose given. The observed modulation in plasma lipid profile might be related to the high level of PUFA found in both bee pollen and propolis (Shinohara et al., 2002; Xu et al., 2009; Rebiai et al., 2017). Moreover, Tatlı Seven et al. (2016) reported a significant increase in tissue PUFA of quail fed bee pollen at $1 \mathrm{~g} / \mathrm{kg}$ diet.

The total white blood cells (TWBCs) did not differ due to diet supplementation. Nevertheless, blood heterophil: lymphocyte ratio $(\mathrm{H} / \mathrm{L})$ is an index of oxidative stress. Quail groups supplemented with Pro and $\mathrm{Bp}$ had lower $\mathrm{H} / \mathrm{L}$ ratio by 30 and $26 \%$, respectively, compared to the control group. The Pro+Bp supplementation showed further reduction of $\mathrm{H} / \mathrm{L}$ ratio reached to $35 \%$. A consistent result on $\mathrm{H} / \mathrm{L}$ ratio reduction was reported by Hosseini et al. (2016), when propolis and bee pollen were supplemented to heat stressed broiler chickens. Moreover, Abass et al. (2017) reported a significant reduction in H/L ratio in turkey poults subjected to oxidative stress inducted by paraquat injection and feed propolis compared to unsupplemented stressed birds. Although, no significant difference was found when propolis supplemented to unstressed bird compared to the control. This conflicted result could be contributed to the difference in bird species and the production type.

\section{CONCLUSION}

The present study revealed that propolis and bee pollen supplementation, at the level of $1 \mathrm{~g} / \mathrm{kg}$ and $2 \mathrm{~g} / \mathrm{kg}$ diet, respectively; to laying quail diet improved the production performance and ameliorated blood constituent levels. A synergistic effect was observed in plasma albumin, calcium and H/L ratio. Propolis supplementation with or without bee pollen has the most pronounced effect on increasing egg number, egg weight and reducing plasma triglycerides levels. We recommend supplementing the diet of laying quail with propolis and/or bee pollen to improve productivity, enhance egg quality and ameliorate the immune response of laying quail.

\section{REFERENCES}

Abass, A. O., N. N. Kamel, W. H. Khalifa, G. F. Gouda, M. A. F. El-Manylawi, G. M. K. Mehaisen, and M. M. Mashaly (2017). Propolis supplementation attenuates the negative effects of oxidative stress induced by paraquat injection on productive performance and immune function in turkey poults. Poultry Science, 96 (12):4419-4429.

Al-Obaidi, F. A. and S. M. J. Al-Shadeedi (2017). Comparison some native fowls (chicken, mallard ducks quail and turkey) in components and chemical composition of the eggs in Iraq. Al-Anbar Journal of Veterinary Science, 10(1):65-69.

Ares, A. M., S. Valverde, J. L. Bernal, M. J. Nozal, J. Bernal (2018). Extraction and determination of bioactive compounds from bee pollen. Journal of Pharmaceutical and Biomedical Analysis, 147:110124. 
Attia, Y. A., A. Al-Hanoun, A. E. Tag El- Din, F. Bovera, and Y. E. Shewika (2011a). Effect of bee pollen levels on productive, reproductive and blood traits of NZW rabbits. Journal of Animal Physiology and Animal Nutrition, 95(3):294-303.

Attia, Y. A., A. Al-Hanoun, and F. Bovera (2011b). Effect of different levels of bee pollen on performance and blood profile of New Zealand White bucks and growth performance of their offspring during summer and winter months. Journal of Animal Physiology and Animal Nutrition, 95(1):17-26.

Attia, Y. A., A. E. A. Al-Hamid, M. S. Ibrahim, M. A. Al-Harthi, F. Bovera, and A. S. El-Naggar (2014). Productive performance, biochemical and hematological traits of broiler chickens supplemented with propolis, bee pollen, and mannan oligosaccharides continuously or intermittently. Livestock Science, 164:87-95.

Babaei, S., S. Rahimi, M. A. KarimiTorshizi, G. Tahmasebi, and S. N. Khaleghi Miran (2016). Effects of propolis, royal jelly, honey and bee pollen on growth performance and immune system of Japanese quails. Veterinary Research Forum, 7(1):13-20.

Bonvehí, S. J. and R. E. Jordà (1997). Nutrient composition and microbiological quality of honeybeecollected pollen in Spain. Journal of Agricultural and Food Chemistry, 45(3):725-732.

Campos, M. G. R., S. Bogdanov, L. B. de Almeida-Muradian, T. Szczesna, Y. Mancebo, C. Frigerio and F. Ferreira (2008). Pollen composition and standardisation of analytical methods. Journal of Apicultural Research, 47(2):154-161.

Choi, S. H., K. T. Song and H. R. Oh (2001). Cholesterol contents and fatty acid composition of chukar, pheasant, guinea fowl and quail egg yolk. Asian-Aust. Journal of Animal Science, 14(6):831-836.

Das, S. K., A. Biswas, R. P. Neema and B. Maity (2010). Effect of soybean meal substitution by different concentrations of sunflower meal on egg quality traits of white and coloured dwarf dam lines. British Poultry Science, 51:427-433.

Duncan, D.B. (1955). Multiple range and multiple F-test. Biometrics, 11:1-42.

El-Tarabany, M. S. (2016). Effect of thermal stress on fertility and egg quality of Japanese quail. Journal of Thermal Biology, 61:38-43.

Farag, S. A. and T. K. El-Rayes (2016). Effect of bee-pollen supplementation on performance, carcass traits and blood parameters of broiler chickens. Asian Journal of Animal and Veterinary Advances, 11(3):168177.

Gehad, A. E., G. M. Mehaisen, A. O. Abbas and M. M. Mashaly (2008). The role of light program and melatonin on alleviation of inflammation induced by lipopolysaccharide injection in broiler chickens. International Journal of Poultry Science, 7:193-201.

Haščík, P., A. Pavelková, M. Bobko, L. Trembecká, I. O. E. Elimam, and M. Capcarová (2017). The effect of bee pollen in chicken diet. World's Poultry Science Journal, 73(3):643-650.

Haugh, R. R. (1937). The Haugh unit for measuring egg quality. U.S. Egg Poultry Magazine, 43:572-573.

Hosseini, S. M., M. Vakili Azghandi, S. Ahani, and R. Nourmohammadi (2016). Effect of bee pollen and propolis (bee glue) on growth performance and biomarkers of heat stress in broiler chickens reared under high ambient temperature. Journal of Animal and Feed Sciences, 25(1):45-51.

Keerthana, M. and R. Renuka (2017). Nutritional and biochemical aspects of poultry feed - a review. International Journal of Recent Scientific Research, 8(12):22615-22617.

Khan, S. H. (2017). Recent advances in role of propolis as natural additive in poultry nutrition. Journal of Apicultural Science, 61(2):167-183. 


\section{Desoky and Kamel}

Kročko, M., M. Čanigová, J. Bezeková, M. Lavová, P. Haščík, V. Ducková (2012). Effect of nutrition with propolis and bee pollen supplements on bacteria colonization pattern in gastrointestinal tract of broiler chickens. Animal Science and Biotechnologies, 45(1):63-67.

Loetscher, Y., M. Kreuzer and R. E. Messikommer (2014). Late laying hens deposit dietary antioxidants preferentially in the egg and not in the body. Journal of Applied Poultry Research, 23:647-660.

Lotfy, M. (2006). Biological activity of bee propolis in health and disease. Asian Pacific Journal of Cancer Prevention, 7:22-31.

Mehaisen, G. K., R. M. Ibrahim, A. A. Desoky, H. M. Safaa, O. A. El-Sayed and A. O. Abass (2017). The importance of propolis in alleviating the negative physiological effects of heat stress in quail chicks. Plos one, 12(10):e0186907.

Mohammed, B. R. and C. Ejiofor (2015). The Prospects and limitations of Japanese quail (Coturnix coturnix japonica) production in Nigeria- A Review. International Journal of Multidisciplinary and Current Research, 3:920-926.

NRC (1994). Nutrient Requirements of Poultry. $9^{\text {th }}$ rev. ed. National Academies Press, Washington, DC, USA.

Oliveira, M. D., D. D. Silva, F. Loch, P. Martins, D. Dias, and G. Simon (2013). Effect of bee pollen on the immunity and tibia characteristics in broilers. Brazilian Journal of Poultry Science, 15(4):323-327.

Pascoal, A., S. Rodrigues, A. Teixeira, X. Feas, L. M. Estevinho (2014). Biological activities of commercial bee pollens: Antimicrobial, antimutagenic, antioxidant and anti-inflammatory. Food and Chemical Toxicology, 63:233-239.

Rebiai, A., M. Belfar, M. Mesbahi, N. Sadok, A. Tliba, D. Ghemam and C. Atef (2017). Fatty acid composition of Algerian propolis. Journal of Fundamental and Applied Sciences, 9(3):1656-1671.

Reddy, P. M.,V. R. Reddy, C. V. Reddy and P.S. P. Rap (1979). Egg weight, shape index and hatchability in khaki Campbell duck egg. Indian Journal of Poultry Science, 14:26-31.

Romanoff, A. L. and A. J., Romanoff (1949). The avian egg. John Wiley and sons Inc., New York. USA. pp.1-918.

Roulston, T. A. H. and J. H. Cane (2000). Pollen nutritional content and digestibility for animals. In "Pollen and Pollination”. A. Dafni, M. Hesse, and E. Pacini, ed. Springer Vienna, Vienna.pp 187-209.

SAS (2006). SAS/STAT ${ }^{\circledR} 9.1$ User's Guide. SAS Institute Inc., Cary, NC, USA. 5136 pp.

Shinohara, R., Y. Ohta, T. Hayashi and T. Ikeno (2002). Evaluation of antilipid peroxidative action of propolis ethanol extract. Phytotherapy Research, 16(4):340-347.

Simone-Finstrom, M. and M. Spivak (2010). Propolis and bee health: the natural history and significance of resin use by honey bees. Apidologie, 41:295-311.

Tatlı Seven, P., A. Sur Arslan, İ. Seven, and Z. Gökçe (2016). The effects of dietary bee pollen on lipid peroxidation and fatty acids composition of Japanese quails (Coturnix coturnix japonica) meat under different stocking densities. Journal of Applied Animal Research, 44(1):487-491.

Vali, N. (2008). The Japanese quail: A review. International Journal of Poultry Science, 7:925-931.

Viuda-Martos, M., Y. Ruiz-Navajas, J. Fernández-López, and J. A. Pérez-Álvarez (2008). Functional properties of honey, propolis, and royal jelly. Journal of Food Science, 73(9)-R117-R124.

Wang, J., S. Li, Q. Wang, B. Xin, and H. Wang (2007).Trophic Effect of Bee Pollen on Small Intestine in Broiler Chickens. Journal of Medicinal Food 10(2):276-280. 
Xu, X., L. Sun, J. Dong and H. Zhang (2009). Breaking the cells of rape bee pollen and consecutive extraction of functional oil with supercritical carbon dioxide. Innovative Food Science and Emerging Technologies 10(1):42-46.

Zafarnejad, K., N. Afzali, and M. Rajabzadeh (2017). Effect of bee glue on growth performance and immune response of broiler chickens. Journal of Applied Animal Research, 45(1):280-284.

Zeweil, H. S., S. M. Zahran, M. H. A. Abd El-Rahman, W. M. Dosoky, S. H. Abu Hafsa and A. A. Moktar (2016). Effect of using bee propolis as natural supplement on productive and physiological performance of Japanese quail. Egyptian Poultry Science Journal, 36(1):161-175.

Zhang, L., H. Y. Yue, L. Xu, S. G. Wu, H. J. Yan (2009). Transport stress in broilers: I. blood metabolism, glycolytic potential, and meat quality. Poultry Science, 88:2033-3041. وإنتاج البيض ومكونـات الدم والأداء المناعى للسمان اليابانى البياض المغذى على عليقة مضاف إليها البروبوليز

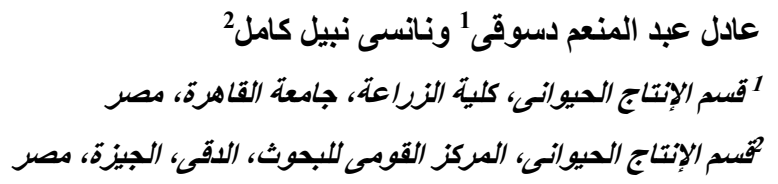

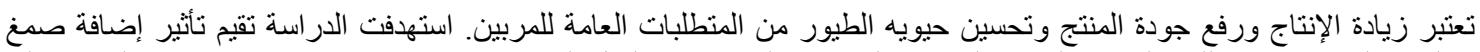

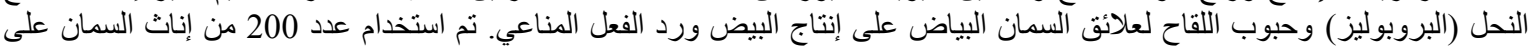

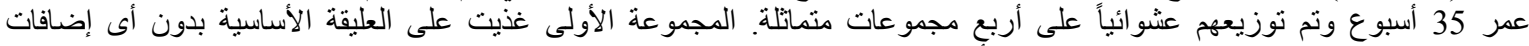

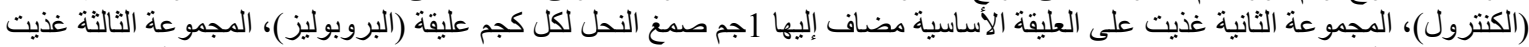

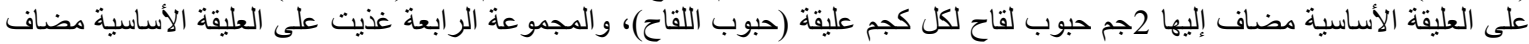

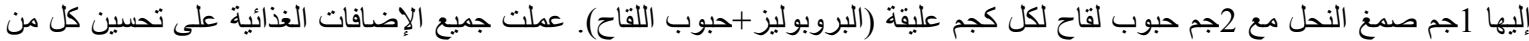

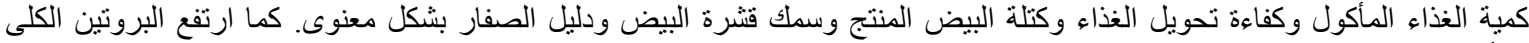

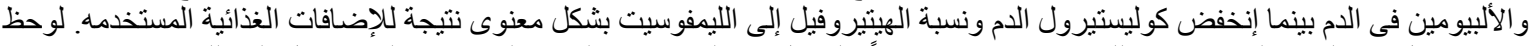

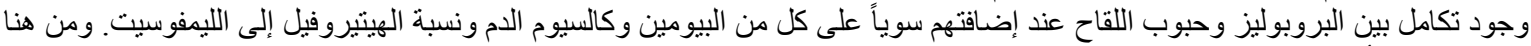

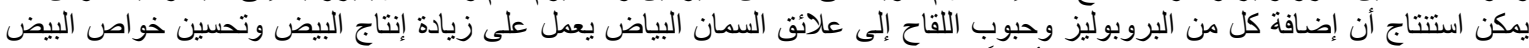

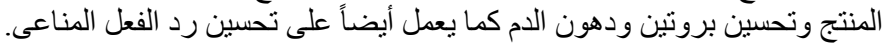

